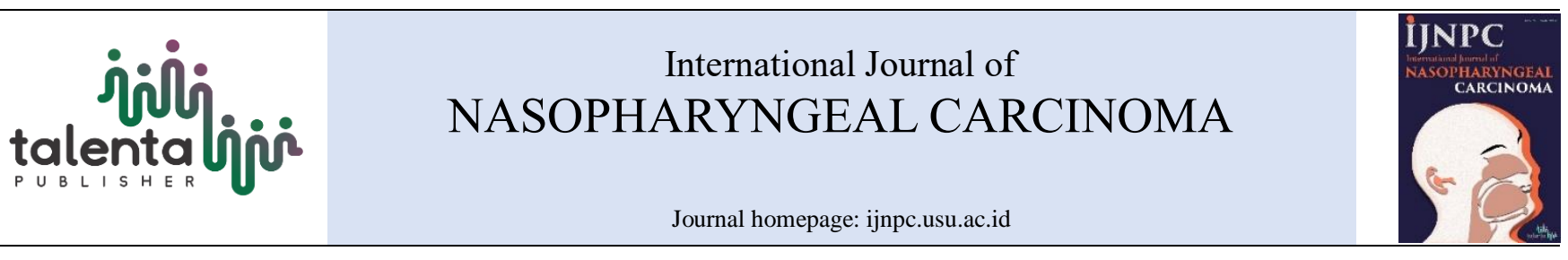

\title{
NASOPHARYNGEAL CARCINOMA IN PANYABUNGAN DISTRICT HOSPITAL
}

\author{
M. Rusli Pulungan* \\ Departement of otorhinolaryngology-Head and Neck Surgery Panyabungan District Hospital
}

\begin{abstract}
Introduction: Nasopharyngeal carcinoma is the most common malignancy found in the head and neck area Non-specific initial symptoms and hidden locations often make it difficult to diagnose early nasopharyngeal carcinoma. The limitations of tools and human resources in the district are a problem in enforcing and finding patients with nasopharyngeal carcinoma in this situation.

Objective: The purpose of this study is to observe the prevalence of nasopharyngeal carcinoma in Departement of Otorhinolaryngology-Head and Neck Surgery Panyabungan District Hospital.

Method: This study collecting data from medical record of Nasopharyngeal carcinoma (NPC) at Panyabungan District Hospital.

Result: The distribution of NPC patients during January-December 2018 there were 10 patients. NPC base on gender male $50 \%$ and female $50 \%$. NPC based on age groups in 46-55 years is 40\%, 56-65 years old is $20 \%$ and 16-25 years, 26-35 years, 36-45 years, and 66-75 years each of 10\%. NPC patients based of clinical appearance is limadenophaty colli is $100 \%$, epistaxis $80 \%$, Nasal congesty $70 \%$.ear fulness $40 \%$ and diplopia $30 \%$. NPC based on histophatologycal types is WHO type I 10\%, WHO type II $50 \%$ and WHO type III $40 \%$.

Conclusion: Nasopharyngeal carcinoma is a malignant tumor originating from the nasopharyngeal epithelium. The patient NPC were diagnosed at an advanced stage. All of patients showed enlargement of neck limph nodes and some showed diplopia.
\end{abstract}

\section{Article Info \\ Keywords: \\ Nasopharyngeal carcinoma, Panyabungan, malignant tumor}

\begin{tabular}{l}
\hline *Corresponding author: \\
Address: Jalan Merdeka No. 40 Panyabungan, \\
Mandailing Natal, North Sumatera, 22919
\end{tabular}

Mandailing Natal, North Sumatera, 22919

e-mail: pulunganmrusli@yahoo.co.id

\section{INTRODUCTION}

Nasopharyngeal carcinoma is a malignancy that grows in the nasopharynx region and originates from the nasopharyngeal epithelium with predilection in the pharyngeal recess (Rosenmuller's fossa). [1-6]. The location of growth of hidden nasopharyngeal carcinoma and non-characteristic clinical symptoms often complicates diagnosing nasopharyngeal carcinoma at an early stage [1] The incidence of nasopharyngeal carcinoma is closely related to certain ethnic. So that the spread of nasopharyngeal carcinoma looks unique. The highest incidence is found in China. Some provinces in China have high cases of nasopharyngeal carcinoma, 15-30 per 100,000 populations. In southern China, especially Hong Kong and Guangzhou, 10-150 cases per 100,000 population a year $[1,7,8]$. In Indonesia Nasopharyngeal carcinoma is the most malignant tumor found in the head and neck area. Fifth place of all malignancies in the body. The incidence of nasopharyngeal carcinoma in Indonesia ranges from 6.2 per 100,000 population each year [1, 2, 7-10].

Nasopharyngeal carcinoma is caused by multifactorial such as: genetics, virus Epstein-Barr infection and environmental influences [1, 8, 11]. Genetic factors in correlation analysis indicate a relationship between the susceptibility of nasopharyngeal carcinoma with HLA (human leukocyte antigen) and p4502E (CYP2EI) enzyme coding genes. In many literature it is stated that Epstein-Barr virus infection is the dominant etiology for nasopharyngeal carcinoma. Relationship between nasopharyngeal carcinoma with Epstein-Barr virus was found in 1966, based on serological studies, found EBV DNA and EBV Nuclear antigen (EBNA) in patients with nasopharyngeal carcinoma [8, 9, 11, 12].

Symptoms and signs of nasopharyngeal carcinoma can be divided into 4 groups: 1) nasopharyngeal symptoms can be mild epistaxis or nasal obstruction $[1,2,5]$. At an advanced stage the tumor enters the nasal cavity and the paranasal sinuses. Nasopharyngeal examination needs to be done carefully. The examination is done using a glass or nasopharyngoscope. Often the tumor has grown in the nasopharynx but symptoms have not yet appeared. 2). Disorders of the ear are early symptoms that arise because the tumor site is close to the Eustachian tube. The tumor closes the Eustachian tube. The disorder can be tinnitus, feels full in the ear, pain in the ear and hearing decreases. 3) Disorders of the eye occur because the tumor extends to the intracranial via the foramen lacerum. This causes interference with cranial nerves III, IV, VI. Impaired eyeball movements cause diplopia. Advanced tumor processes can extend to the cranial nerves IX, X, XI, XII if the tumor passes through the jugular foramen. 4) Metastasis to the neck lymph nodes in the form of a lump in the neck. Enlargement of neck lymph nodes is a disorder that often causes patients to come for treatment $[1,2,5]$.

Histopathology, WHO in 1992 classified nasopharyngeal carcinoma into 3 types histologically: Squamous cell cratinaized carcinoma (WHO type 1); squamous differentiated non-keratin carcinoma cells (WHO type 2); squamous non-differentiated non-keratin carcinoma cells (WHO type 3). WHO type 1 is found in North America while in South China only 2\%, for WHO type $212 \%$ is found in North America while in South China only 3\% and WHO type 3 is the most common type in South China which reaches $95 \%[7,8,13]$.

\subsection{Staging}

Clinical staging of the tumor represents 4 stages. Based on the 8 th edition of AJCC, staging Primary Tumors (T); Tx is a primary tumor that cannot be defined. T0, does not contain primary tumors but EBV positif cervical node(s) involvement. Tis, Carcinoma in situ. T1 the tumor is confined to the nasopharynx or extends to the oropharynx and/or nasal cavity without parapharyngeal involvement. T2, the tumor extends to parapharyngeal space and/or adjacent soft tissue involvement (medial pterygoid, lateral pterygoid, prevertebral muscle). T3 Tumor enters bone structure at skull base, cervical vertebra, pterygoid structures, and/or paranasal sinuses. T4, the tumor extends to the intracranial, cranial nerves, hypopharynx, orbit, parotid gland, and/or extensive soft tissue infiltration beyond the lateral surface of the lateral pterygoid muscle.

Regional Lymph Nodes $(\mathrm{N})$. Nx Regional lymph nodes cannot be defined. NO There is no metastasis to regional lymph nodes. N1 Unilateral metastasis in cervical lymph node(s), and/or unilateral/bilateral metastasis in retropharyngeal limph node(s), measuring $6 \mathrm{~cm}$ or less above the caudal border of cricoid cartilage. N2 bilateral metstasis in cervical lymph nodes size $6 \mathrm{~cm}$ or less above the caudal border of cricoid cartilage. N3 unilateral/bilateral metastasis in 
retropharyngeal limph node(s) larger than $6 \mathrm{~cm}$ in greates dimention and/or extension below the caudal border of cricoid cartilage. Metastasis (M): MX distant metastasis cannot be defined. M0 There are no distant metastases. M1 There is distant metastasis. Stage I is T1N0M0 local disease in soft tissue only. Stage II is T1N1M0 or T2N0M0 or T2N1M0 local disease in soft tissue only. Stage III is T3N0M0 or T1N2M0, T2N2M0, T3N1M0, T3N2M0. Stage IVa is T1,2,3,4 N3 M0, or T4 N0,1,2,3,M0. IVb Any T, Any N M1. [14].

Diagnosis of nasopharyngeal carcinoma is primarily based on history, physical examination and imaging. For definitive diagnosis a biopsy of the lesion is required. Biopsy can be performed in the officer or in the operating room by rigid or flexible endoscope and has a high specificity $(99.6 \%)[2,5,6,15]$.

The primary tumor extended should be evaluated by CT Scan and/or MRI. MRI is the preferred modality of choice for imaging nasopharyngeal carcinoma. MRI is more sensitive than CT scan for the detection of the extension of the primary tumor [6].

\section{MATERIAL AND METHODS}

The design of this study is a descriptive study with a retrospective crosssectional approach. The sample including the entire population (total sampling) of nasopharyngeal carcinoma patients based on histopathological examination at Panyabungan District Hospital from January-December 2018. Collecting data from medical record and result of examination of histopathology of centra diagnostic of pathology anatomy Faculty of medicine of Andalas University. Data on nasopharyngeal carcinoma cases including: gender, age, clicical appearance and histopathology type.

\section{RESULT}

There were 10 nasopharyngeal carcer patients in the Departement of Otorhinolaryngology-Head and neck surgery, Panyabungan District Hospital, Panyabungan during the January-December 2019.

Table 1. The prevalence of Nasopharyngeal carcinoma based on gender

\begin{tabular}{lcc}
\hline Gender & Frequency (n) & Percentage (\%) \\
\hline Male & 5 & 50 \\
Female & 5 & 50 \\
\hline Total & $\mathbf{1 0}$ & $\mathbf{1 0 0}$ \\
\hline
\end{tabular}

Table 2. The Distribution of nasopharyngeal carcinoma based on the age

\begin{tabular}{lcc}
\hline Age group (year) & Frequency (n) & Percentage (\%) \\
\hline $16-25$ & 1 & 10 \\
$26-35$ & 1 & 10 \\
$36-45$ & 1 & 10 \\
$46-55$ & 4 & 40 \\
$56-65$ & 2 & 20 \\
$66-75$ & 1 & 10 \\
\hline Total & $\mathbf{1 0}$ & $\mathbf{1 0 0}$ \\
\hline
\end{tabular}

Table 3. Clicinal Appearence of Nasopharyngeal carcinoma

\begin{tabular}{lcc}
\hline Clinical Appearence & Frequency (n) & Percentage (\%) \\
\hline Nasal Congesti & 7 & 70 \\
Epistaxis & 8 & 80 \\
Ear Fulness & 4 & 40 \\
Diplopia & 3 & 30 \\
Limadenopaty colli & 10 & 10 \\
\hline
\end{tabular}

Table 4. Distribution of histopatological types of nasopharyngeal carcinoma

\begin{tabular}{llll}
\hline Histophatology type & & Frequency (n) & Percentage (\%) \\
& & & \\
\hline WHO type I & 1 & 10 \\
WhO type II & 5 & 50 \\
WHO type III & 4 & 40 \\
\hline Total & $\mathbf{1 0}$ & $\mathbf{1 0 0}$ \\
\hline
\end{tabular}

\section{DISCUSSION}

Panyabungan district hospital is a referral hospital from all primary care unit in Mandailing Natal District. This hospital is a type C hospital. Mandailing Natal district is a vast area of 653,542 ha or $9.24 \%$ of the area of North Sumatra Province.
The population in 2015 was 430,894 people [16]. Topographically, Mandailing Natal is an area consisting of lowlands, mountains and beaches. This topography has made it difficult for residents to access health facilities. This condition makes the detection of nasopharyngeal carcinoma increasingly difficult.

Early detection of nasopharyngeal carcinoma in areas such as Mandailing Natal is very dependent on health workers in the villages and at the primary care unit. Health services in villages organized by midwives and paramedics and general practitioners are not always able to detect nasopharyngeal carcinoma at an early stage.

The all of patients who have been diagnosed with nasopharyngeal carcinoma have clinical symptoms at an advanced stage. Enlarged neck lymph nodes were found in all patients. Other symptoms such as diplopia are advanced symptoms of nasopharyngeal carcinoma.

All patients who were reported were diagnosed with nasopharyngeal carcinoma at an advanced stage. Non-specific symptoms in the early stages caused this disease to be difficult to detect. Nasopharyngeal examination using laryngeal glass in detecting abnormalities in the nasopharynx is needed. The ability of health workers in the primary care unit to recognize symptoms of nasopharyngeal carcinoma is needed for early detection. In district hospitals nasopharyngeal carcinoma can be detected using nasopharyngeal endoscopy so that detection is easier to do. However, a definite diagnostic through anatomy pathology examination still does not exist so that biopsy samples are still sent to the Anatomy Pathology laboratory in Medan or Padang.

\section{CONCLUSION}

Nasopharyngeal carcinoma is a malignant tumor originating from the nasopharyngeal epithelium. The patient NPC were diagnosed at an advanced stage. All of patients showed enlargement of neck limph nodes and some showed diplopia.

\section{REFERENCE}

[1] Adham M, Kurniawan AN, Muhtadi AI, Roezin A, Hermani B, Gondhowiardjo S, et al. Nasopharyngeal carcinoma in Indonesia: epidemiology, incidence, signs, and symptoms at presentation. Chinese journal of cancer. 2012;31(4):185.

[2] Roezin AA, M. Karsinoma Nasofaring. Buku Ajar Ilmu Kesehatan Telinga Hidung Tenggorok Kepala dan Leher. 2008;6:5.

[3] Wei WI, Sham JS. Nasopharyngeal carcinoma. The Lancet. 2005;365(9476):2041-54.

[4] James PM, K. Robbins, T. Carcinoma of the oral cavity, pharynx, and Esophagus. Essential Otolaryngology Head \& Neck Surgery. 2008;9th:70839.

[5] Wei W, I. Nasopharyngeal Cancer. Head \& Neck Surgery Otolaryngology. 2006;4th:1657-73.

[6] Chan A, Felip E, Group EGW. Nasopharyngeal cancer: ESMO clinical recommendations for diagnosis, treatment and follow-up. Annals of Oncology. 2009;20(suppl 4):iv123-iv5.

[7] Harianto. Nasopharyngeal carcinoma characteristic in Arifin Achmad Hospital in January-october 2018. International Journal of Nasopharyngeal Carcinoma. 2019;1(3):103-4.

[8] Rahman S, Budiman BJ, Subroto H. Faktor risiko non viral pada karsinoma nasofaring. Jurnal Kesehatan Andalas. 2015;4(3).

[9] Cao S-M, Simons MJ, Qian C-N. The prevalence and prevention of nasopharyngeal carcinoma in China. Chinese journal of cancer. 2011;30(2):114.

[10] Jemal A, Bray F, Center MM, Ferlay J, Ward E, Forman D. Global cancer statistics. CA: a cancer journal for clinicians. 2011;61(2):69-90.

[11] Tsao SW, Yip YL, Tsang CM, Pang PS, Lau VMY, Zhang G, et al. Etiological factors of nasopharyngeal carcinoma. Oral oncology. 2014;50(5):330-8.

[12] Fang C-Y, Huang S-Y, Wu C-C, Hsu H-Y, Chou S-P, Tsai C-H, et al. The synergistic effect of chemical carcinogens enhances Epstein-Barr virus reactivation and tumor progression of nasopharyngeal carcinoma cells. PloS one. $2012 ; 7(9)$.

[13] Stelow EB, Wenig BM. Update from the 4th edition of the World Health Organization classification of head and neck tumours: nasopharynx. Head and neck pathology. 2017;11(1):16-22.

[14] Lee AW, Ng W, Chan L, Chan OS, Hung W, Chan C, et al. The strength/weakness of the AJCC/UICC staging system for nasopharyngeal cancer and suggestions for future improvement. Oral oncology. 2012;48(10):1007-13.

[15] Sham J, Choy D, Wei W, Ng M, Zong Y, Guo Y, et al. Detection of subclinical riasopharyngeal carcinoma by fibreoptic endoscopy and multiple biopsy. The Lancet. 1990;335(8686):371-4.

[16] Natal BPSKM. Mandailing Natal Dalam Angka 2018. Panyabungan: BPS Madina; 2018 